\title{
Efektifitas dan Kepuasan Pasien pada Pelayanan Keperawatan Maternitas di Rshs Bandung
}

\author{
Laili Rahayuwati ${ }^{1}$, Ermiati $^{2}$, Mira Trisyani ${ }^{2}$ \\ ${ }^{1}$ Fakultas Keperawatan Universitas Padjadjaran, \\ ${ }^{2}$ Bagian Keperawatan Maternitas, Fakultas Keperawatan Universitas Padjadjaran
}

\begin{abstract}
Abstrak
Meskipun secara global ada perubahan dalam tren epidemiologi dari penyakit menular ke penyakit kronis, prevalensi dan insiden penyakit menular serta MMR (Maternal Mortality Rate) atau AKI (Angka Kematian Ibu) dan AKB (Angka Kematian Bayi) di Indonesia masih tinggi. Tingginya angka kematian yang terjadi selama persalinan, diakibatkan faktor langsung seperti komplikasi kebidanan, perdarahan, dan eklampsia; atau faktor tidak langsung, seperti kekurangan gizi, penyakit menular dan tidak menular. Pada tahun 2000, Fakultas Keperawatan Unpad bekerja sama dengan RSHS membangun sebuah model dari ruang perawatan, yang berafiliasi dengan ruang ginekologi kebidanan. Model dibangun dengan tujuan untuk; meningkatkan kualitas pelayanan kesehatan; untuk mengembangkan pengalaman mahasiswa dengan pasien; menyediakan pendidik perawat berkualitas untuk menunjang siswa; mendorong mahasiswa untuk meningkatkan hasil praktek klinis. Tujuan penelitian ini adalah untuk memberikan informasi dan gambaran tentang efektifitas dan tingkat kepuasan pasien pada pelayanan keperawatan maternitas. Hasil penelitian menunjukkan di satu sisi, ada beberapa kekhawatiran berkaitan dengan efektivitas perawatan persalinan, yaitu; rasio bidan dan pasien tidak ideal; ada satu konsultan ginekolog obstetri dan satu dokter untuk setiap kamar. Delapan puluh persen lebih terapi delegasi untuk bidan dilakukan melalui komunikasi langsung, bukan melalui catatan medis. Di sisi lain, tingkat kepuasan pasien yang menerima perawatan bersalin adalah $58 \%$, dan $42 \%$ tidak puas. Kesimpulan dari penelitian ini merekomendasikan untuk mengambil perencanaan strategis yang komprehensif untuk meningkatkan pelayanan keperawatan dan kebidanan yang melibatkan semua pihak terkait di pemerintah, masyarakat sipil, pelayanan, pendidikan, dan organisasi profesi.
\end{abstract}

Kata Kunci: Asuhan Keperawatan Maternitas, Efektifitas, Kepuasan pasien.

\section{Effectiveness and Patients'Satisfaction of Maternity Nursing Care in Hasan Sadikin Hospital Bandung}

\begin{abstract}
Although there is a change in the trend of epidemiology from infectious diseases to chronic diseases, the prevalence and incidence of infectious diseases as well as MMR (Maternal Mortality Rate) and IMR (infant mortality rate) in Indonesia is still high. High mortality rate occur during childbirth, whether due to direct factors such as obstetric complications, bleeding, and eclampsia; or indirect factors, such as insufficient nutrition, infectious and non-infectious diseases. In 2000, the Faculty of Nursing of the Unpad in collaboration with RSHS built a model of treatment room, which was affiliated with obstetric gynecology room. The model aimed to; improve the quality of health care services; to develop the students' experiences with patients; provide quality nurse educators to support students; encourage students to improve the results of clinical practice. The objective of this study was to give an information and description to patient's satisfaction and an efficiency process of for maternity nursing service. The results showed: in one hand, there were some concerns with regard to the effectiveness of maternity care, namely: the ratio of midwife and patient was not ideal; there was one obstetric gynecologist consultant and one medical doctor for every room. Most of therapy delegation to midwife has been done by direct communication, rather than through medical records. In the other hand, the satisfaction level of patients who received maternity nursing care was $58 \%$, and $42 \%$ were dissatisfied. This study recommends to take a comprehensive strategic planning for improving nursing and midwifery services that involve all relevant stakeholders in the government, civil society, service delivery, education, and professional organizations.
\end{abstract}

Keywords: Effectiveness, Maternity Nursing Care, Patient's Satisfaction.

Korespondensi:

Laili Rahayuwati, MSc

Fakultas Keperawatan Universitas Padjadjaran

Jl. Raya Bandung-Sumedang km 21 Jatinangor

Mobile : 08122138385

Email: laili.rahayuwati@unpad.ac.id 


\section{Pendahuluan}

Perhatian terhadap tingginya kejadian AKI dan AKB masih merupakan agenda utama pelayanan kesehatan di Indonesia. Beberapa studi menunjukkan bahwa sekitar 350-400 kematian terjadi pada ibu di setiap 100.000 kelahiran hidup. Hal ini berarti bahwa terjadi satu kematian dalam setiap jam yang diakibatkan komplikasi kehamilan, kurangnya layanan emergensi bidang maternitas dan obstetrik, maupun keterlambatan rujukan. Berdasarkan Laporan Pencapaian Tujuan Pembangunan Milenium di Indonesia tahun 2014 serta data dari Survei Demografi dan Kesehatan Indonesia (SDKI) tahun 2012, diketahui bahwa AKI di Indonesia pada tahun 2007 adalah sebanyak 228 per 100.000 kelahiran hidup. Namun, pada tahun 2012 terjadi peningkatan menjadi 359 per 100.000 kelahiran hidup. Angka tersebut sangat memprihatinkan mengingat bahwa Indonesia menjadi pemilik angka tertinggi kematian ibu di ASEAN. Angka ini belum dapat mencapai target global MDGs (Millenium Development Goals) ke-5 yaitu menurunkan angka kematian ibu menjadi 102 per 100.000 kelahiran hidup pada tahun 2015, terlebih lagi untuk mencapai target SGDs pada tujuan ke-3 yang menjadikan AKI pada tahun 2030 menjadi 70 per 100.000 kelahiran hidup. ${ }^{1}$

Penyebab AKI di Indonesia saat melahirkan selama periode 2010 - 2013 masih tetap sama yaitu perdarahan, hipertensi, infeksi, abortus dan lain-lain. Di Jawa Barat dalam kurun waktu 5 tahun (2007-2012) angka kematian bayi berdasarkan hasil SDKI mengalami penurunan sebesar 23,07\% dari 39 per 1000 kelahiran hidup menjadi 30 per 1000 kelahiran hidup. Hal tersebut masih jauh dari target MDG's 2015 yaitu sebesar 23 per 1000 kelahiran. Data lainnya dari Riskesdas tahun 2007 penyebab kematian perinatal (0-6 hari) terbanyak ke dua $(32.4 \%)$ disebabkan karena prematuritas. ${ }^{2}$

Rumah sakit merupakan bagian dari sistem praktik kesehatan yang memberikan layanan kepada masyarakat dalam rangka meningkatkan status kesehatan. Umumnya, rumah sakit mempunyai peran sentral dalam empat area, yaitu: penyediaan tenaga kesehatan profesional; pemberian layanan kesehatan pada pasien; pendidikan; penelitian dan pengabdian masyarakat. Di Indonesia terdapat empat klasifikasi rumah sakit berdasarkan jenis layanan dan fasilitas yang dimiliki mulai dari tipe A, B, C, D. Rumah Sakit Hasan Sadikin merupakan rumah sakit kelas A yang merupakan rumah sakit rujukan, yaitu: mewakili institusi pelayanan kesehatan yang bertanggung jawab menangani perawatan medis darurat; menjadi rumah sakit pendidikan bagi penyedia layanan kesehatan (staf medis); layanan kesehatan yang berperan dalam meningkatkan standar kesehatan masyarakat di Propinsi Jawa Barat.

Berdasarkan kronologi tahun 2000 di Rumah Sakit Hasan Sadikin, tim keperawatan yang disponsori oleh Fakultas Keperawatan Unpad telah membangun model ruang perawatan. Ruang model ini dibangun untuk; meningkatkan kualitas pelayanan kesehatan; pengembangan pengalaman mahasiswa dengan pasien; penyediaan pendidik perawat yang berkualitas untuk mendukung kegiatan mahasiswa; mendorong mahasiswa untuk meningkatkan hasil praktek klinis.

Perawat di rumah sakit mempunyai peran penting sebagai salah satu tim layanan kesehatan. Sebagai caregiver, perawat memberikan layanan pasien, berkolaborasi dengan dokter dan profesi kesehatan dalam memberikan layanan. Perawat juga berkoordinasi dengan pasien dan keluarga dalam meningkatkan kualitas layanan dan kualitas hidup pasien. Sebagai educator, perawat memberikan pendidikan pada pasien, melakukan pencegahan infeksi dan kenyamanan pasien serta menjaga kesehatan lingkungan rumah sakit. Sebagai advocator, perawat memberikan ajakan pada pasien dan keluarga dalam rangka meningkatkan status kesehatan pasien dalam berbagai situasi. ${ }^{3}$

Penelitian evaluasi (evaluation study) ini bertujuan menghasilkan informasi tentang keberlangsungan serta memberikan penilaian terhadap keberhasilan suatu program, baik ditinjau dari ketersediaan sarana fisik maupun sumberdaya pendukungnya. Penelitian evaluasi ini menekankan pada evaluasi proses, yang merupakan bagian dari evaluasi formatif. Dalam hal ini, evaluasi proses bertujuan menilai apakah unsur-unsur tertentu seperti fasilitas, staf, ruang, atau layanan yang disediakan atau yang didirikan sesuai dengan rencana program yang diberikan. Evaluasi proses juga menilai proses perencanaan/ pengembangan program dalam menunjang pengembangan program sesuai dengan kebutuhan pasien. Selain itu, evaluasi proses juga melibatkan dokumentasi dan deskripsi spesifik program asuhan keperawatan maternitas meliputi bentuk, pelaku dan waktu kegiatan. Yang termasuk dalam evaluasi proses antara lain pemantauan tentang partisipasi sumber daya manusia sampai dan tingkat pelaksanaan program. Evaluasi proses ini di dukung beberapa dokumentasi berikut: keberadaan staf kesehatan dan non kesehatan, kondisi pasien, kualitas rencana pelaksanaan, kesesuaian antara rencana dengan pelaksanaan, metode, materi, media, dan instrumen yang digunakan.

Tujuan umum penelitian adalah melakukan 
pengkajian asuhan keperawatan maternitas di Ruang Obstetrik Ginekologi. Adapun tujuan khusus adalah: Mengkaji efektifitas dan kualitas asuhan keperawatan maternitas; Mengidentifikasi kepuasan pasien pada kualitas asuhan keperawatan maternitas.

\section{Metode}

Rancangan studi, penelitian evaluasi ini dilakukan di Rumah Sakit Hasan Sadikin, Bandung khususnya di Ruang Kemuning sebagai ruang rawat inap pasien dengan kasus obstetric ginekologi termasuk di dalamnya postpartum dan keperawatan kesehatan reproduktif.

Studi kasus dilakukan sebagai strategi evaluasi yang paling efektif untuk mendapatkan informasi tentang kegiatan suatu program, baik secara spesifik maupun umum. Studi kasus ini dimanfaatkan untuk menganalisis situasi terkait: lokasi pelayanan kesehatan, tingkat keterampilan dan koordinasi antara perawat dan perawat mahasiswa, dan pelaksanaan dokumentasi kegiatan keperawatan maternitas.

Variabel utama dalam penelitian ini adalah: program asuhan keperawatan maternitas, yang terkait dengan kasus obstetrik dan ginekologi; standar pelayanan keperawatan maternitas. Adapun indikator yang relevan dalam pengukuran variabel asuhan keperawatan maternitas adalah: tahapan asuhan keperawatan; implementasi nilainilai keperawatan pada pasien; perbandingan karakteristik asuhan keperawatan maternitas berdasarkan data dokumentasi 1 periode sebelum pelaksanaan model ruangan. Adapun, pengukuran efektifitas kualitas asuhan keperawatan maternitas mengacu pada: apakah program memenuhi tujuan yang telah ditetapkan; apakah adanya peningkatan kualitas perawat secara professional; bagaimana akuntabilitas standar penilaian pasien terhadap keperawatan maternitas. Sedangkan efisiensi pelayanan keperawatan maternitas mengacu pada: apakah hasil program dapat dicapai dengan biaya yang murah; bagaimana keberlangsungan pelayanan keperawatan maternitas pada periode mendatang terkait dengan beberapa indikator seperti pengembangan model kemitraan layanan antar profesi kesehatan.

Populasi dan sampel populasi adalah petugas kesehatan, mahasiswa praktik dan pasien yang berinteraksi dalam ruang Kemuning selama periode 1 bulan. Pengambilan sampel dilakukan secara accidental sampling, meliputi sampel perawat (5 orang), mahasiswa keperawatan (15 orang), serta sampel pasien (22 orang).

Pengumpulan data primer dilakukan melalui: wawancara kepada petugas kesehatan dan mahasiswa keperawatan; pengisian kuesioner kepada 22 pasien/responden; observasi terhadap situasi klinik di ruang Kemuning dalam kaitan dengan proses keperawatan maternitas. Sedangkan, data sekunder didapatkan dari dokumentasi yang ada di ruang Kemuning, metode dokumentasi ini dilakukan melealui hasil monitor adanya pertemuan-pertemuan yang dilakukan petugas kesehatan maupun dalam proses evalusi bimbingan mahasiswa terhadap kompetensi klinis dan hal lain yang relevan. Adapun instumen penelitian adalah pedoman wawancara yang digunakan dalam wawancara dengan petugas kesehatan dan mahasiswa praktik, serta kuesioner yang diberikan pada sampel pasien. Wawancara dengan menggunakan pedoman wawancara meliputi pertanyaan umum terhadap situasi ruang perawatan, dan penjelasan dari para petugas kesehatan dan mahasiswa praktik tentang aspek keperawatan maternitas yang dipahami dan dijalankan. Khusus untuk menilai kepuasan pasien menggunakan instrument ${ }^{4}$ yang merujuk pada indikator tentang pengalaman pasien dalam menerima layanan keperawatan.

Analisis data deskriptif (hasil kuesionerpasien) dilakukan dengan menggunakan SPSS 15 dan disajikan dalam bentuk diagram kue. Sedangkan analisis data kualitatif (hasil wawancara) dilakukan dengan menggunakan langkah berikut: Membuat dimensi kategori; pengelompokan kategori yang akan dianalisis; Melakukan interpretasi berdasarkan pengelompokan kategori atau domain 5 .

\section{Hasil}

Secara umum asuhan keperawatan maternitas bertujuan untuk meningkatkan kesehatan ibu dan anak secara menyeluruh baik pada tingkat fisik, emosi, psikologis, maupun social dan spiritual. Secara spesifik, program tersebut diterjemahkan: Meningkatkan akses layanan untuk status kesehatan yang menyeluruh; Memberikan layanan dasar; Melakukan rujukan sosial dan kesehatan yang diperlukan; Melakukan kolaborasi dalam pengembangan dan perencanaan program kesehatan; Memberikan pendidikan kesehatan; Advokasi mengurangi hambatan layanan kesehatan dan mendukung akses layanan kesehatan sesuai kebutuhan klien.

Efektifitas Pelayanan, sebagai Rumah Sakit rujukan di Provinsi Jawa Barat, RSHS juga merupakan rumah sakit pendidikan. Selain itu, visi rumah sakit adalah menjadi rumah sakit kelas dunia dalam hal pemberian layanan tahun 2017. Adapun misinya adalah memberikan kualitas layanan kesehatan yang teringrasi 
dengan pendidikan dan penelitian. Motonya adalah "Kesehatan Anda adalah prioritas Kami". Ruang Kemuning, RSHS Bandung dintegrasikan menjadi ruang layanan, pendidikan dan penelitian sejak tahun 2013.

Layanan standar yang diberikan berkaitan dengan the maternity care standard yang difokuskan pada perawatan kasus: kehamilan ektopik, ca cervix, ca ovarium, ca vagina, serta semua masalah kesehatan reproduksi. Standar ini memiliki SOP (Standard Operasional Prosedur) berupa pengkajian, analisis data, diagnosis dan rencana intervensi.

Tenaga Kesehatan profesional di Ruangan Kemuning Rumah Sakit Hasan Sadikin, berjumlah 15 orang dengan rincian 13 orang bidan (4 orang D IV Kebidanan dan 9 orang D III Kebidanan) sementara tenaga perawat 2 orang (1 orang Spesialis Keperawatan Maternitas dan 1 orang D III Keperawatan). Berdasarkan data yang ada jumlah perawat yang bekerja di Ruang Kemuning masih sedikit, sementara itu di rumah sakit lain di Jawa Barat justru tidak ada perawat yang ditempatkan di ruangan perawatan obgin dan ginekologi. Ruangan Kemuning khusus obgin menjadi tempat praktik mahasiswa PPDS, keperawatan D III, Ners dan D III Kebidanan. Rasio tenaga kesehatan dengan pasien 1:19. Sarana dan prasarana disediakan dengan baik mulai dari fasilitas ruangan, maupun asuransi kesehatan pemerintah

Peran tenaga kesehatan di ruang Kemuning adalah: Memberikan Asuhan terkait dengan kebutuhan dasar manusia; Informasi tentang kesehatan reproduksi, penyakit, pencegahan kepada pasien; Rehabilitasi pasien; Mendukung pasien dalam kondisi sakit terminal. Peran Dokter Konsultan di ruangan Kemuning khususnya memberikan layanan dan memastikan standar asuhan keperawatan bagi perempuan yang memerlukan kebutuhan medis atau obstetrik kompleks, kondisi akut, maupunkondisi mengancam kedaruratan.

Sebagai rumah sakit pendidikan, yang perlu disediakan adalah peningkatan kompetensi mahasiswa termasuk kognitif, afektif, psikomotor yang berhubungan dengan kesehatan pasien. Sebagai rumah sakit penelitian, tujuan dari lembaga ini adalah untuk meningkatkan pelayanan keperawatan dan kesehatan umum untuk pasien. Model yang diterapkan di ruang kemuning obgin adalah metode tim. Ruangan dipisahkan menjadi 4 kamar, dengan jumlah tempat tidur 38 yang dibagi di setiap kamar 8-10 tempat tidur. Rasio antara petugas dan pasien adalah 1:19, meskipun rasio yang ideal adalah 1:6 (Gillies, 1999). Efektivitas jumlah tenaga kesehatan yang harus mendapat perhatian adalah: Rasio bidan/perawat dan pasien yang tidak ideal, asuhan perawatan cukup efektif di pagi hari dibandingkan malam hari. Mahasiswa (bidan/perawat) membantu untuk memberikan layanan kesehatan melalui beberapa tahap mulai dari pengkajian, pelaksanaan dan evaluasi pasien Ada 1 dokter obgin konsulen dan 1 dokter PPDS untuk setiap kamar.

Kepuasan Pasien, Diagram 1 menunjukkan bahwa hampir sebagian besar responden (58\%) merasa puas dengan asuhan keperawatan yang diberikan, artinya mereka merasa senang dengan pelayanan keperawatan. Sementara $42 \%$ merasa kurang puas dengan layanan keperawatan yang diberikan. Beberapa indikator yang berhubungan dengan kepuasan pasien antara lain: petugas memberikan informasi saat pelayanan seperti informasi tentang operasi, keuangan, jaminan kesehatan serta sikap petugas dinilai baik oleh sebagian besar pasien. Sebaliknya pasien yang tidak puas menyatakan bahwa mereka kurang mendapat informasi tentang pelayanan medis yang seharusnya mereka dapatkan, dan beberapa petugas dinilai belum berpengalaman.

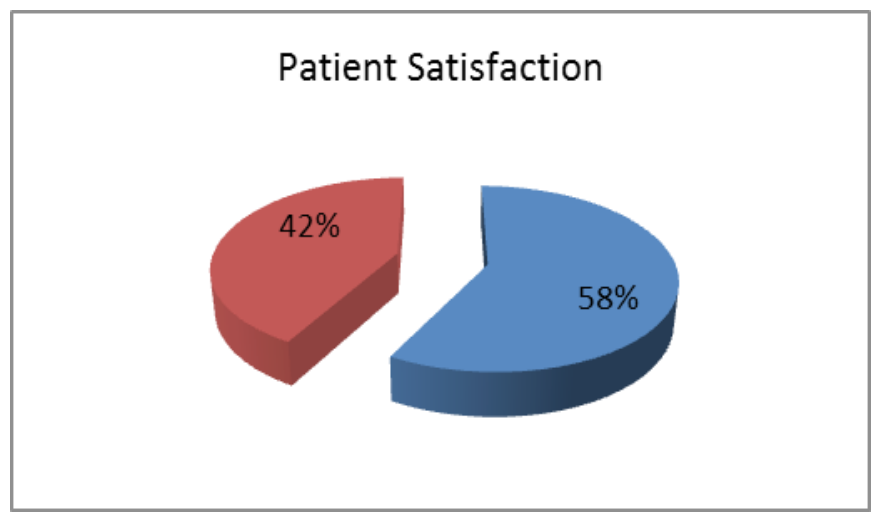

Diagram 1 Kepuasan Pasien pada Layanan Asuhan Keperawatan 


\section{Pembahasan}

Di beberapa negara, asuhan kepada pasien obstetrik dan ginekologi menjadi bagian asuhan keperawatan maternitas dilakukan oleh profesional kesehatan seperti perawat maternitas atau perawat kebidanan. Dalam beberapa tahun terakhir terdapat kesepakatan perawat dan bidan secara global tentang: sertifikasi keperawatan; bidan sertifikasi pasca keperawatan (nursemidwife); bidan sertifikasi. Secara khusus, sertifikat Perawat-Bidan (Certificate Nurse Midwife) diberikan kepada perawat lanjutan yang melakukan praktik atau spesialisasi pendidikan dan pelatihan dalam dua bidang yaitu Keperawatan dan Kebidanan. Fungsi perawat kebidanan/maternitas sebagai penyedia layanan kesehatan primer bagi ibu sehat dan tidak memiliki resiko dalam proses persalinan dan memberikan asuhan keperawatan pada pasien dengan masalah ginekologi.

Di Indonesia, dibandingkan dengan standar global terdapat beberapa perbedaan. Khususnya, layanan obstetrik dan ginekologi di rumah sakit di lakukan dokter, spesialis obstetrik dan ginekologi dan bidan dengan tidak melibatkan perawat. Perawat bekerja di semua bagian ruangan rawat inap kecuali ruangan obgyn dan ginekologi. Sementara itu kompetensi perawat memiliki kemampuan untuk bekerja di ruangan obstetrik dan ginekologi. Saat ini perawat di Indonesia berdasarkan UU Nomor 38 tahun 2014 pasal 4 ayat 2 perawat profesi terdiri dari perawat profesi ners dan spesialis. Pendidikan keperawatan di Indonesia saat ini telah sampai ke jenjang spesialis termasuk didalamnya perawat spesialis maternitas.

Standar dari praktik klinis bertujuan untuk menyediakan jasa layanan praktik keperawatan sesuai dengan panduan gold standar yang di pandu oleh kode etik baik secara umum di semua ruangan maupun di ruang obstetrik dan ginekologi. Jumlah dan kemampuan perawat dalam memberikan asuhan keperawatan di ruangan obstetrik dan ginekologi yang didasari kompetensi, lisensi, sertifikasi merupakan landasan yang tepat dalam menempatkan perawat di ruang obstetri dan ginekologi.

Simpulannya perkembangan ilmukeperawatan telah banyak memunculkan spesialisasi, yang harusnya tidak dimaknai sebagai kompetensi yang tumpang tindih dengan profesi lain. Tujuan profesi, baik secara keilmuan maupun praktik mempunyai cakupan yang universal, sesuai dengan kebutuhan masyarakat dan dikembangkan sesuai kebijakan yang berlaku. Semuanya ada dalam satu sistem kesehatan nasional. Oleh karena itu, tantangan keperawatan maternitas, adalah tantangan profesi untuk melakukan pengkajian terhadap kebutuhan keperawatan maternitas pada klien dengan meluaskan kerjasama interdisipliner, serta menghilangkan hirarki keilmuan dan praktik untuk kepentingan pasien dan masyarakat.

Karena keperawatan maternitas adalah melibatkan banyak ilmu, sehingga perawat spesialisasimternitas perlumengambilpendekatan eklektik, memilih yang terbaik (metode, pola asuhan) dari berbagai sumber. Selanjutnya, hal ini direkomendasikan untuk suatu perencanaan strategis yang komprehensif untuk pelayanan keperawatan dan kebidanan, dengan melibatkan semua pihak terkait baik pemerintah, masyarakat sipil, pelayanan, pendidikan dan organisasi profesional.

\section{Daftar Pustaka}

1 Charmin, B. 2015. Radio Republik Indonesia: AKI Jadi Tanggung Jawab Pemerintah dan Seluruh Lapisan Masyarakat. Diperoleh dari http://rri.co.id/post/berita/221846/nasional/ aki_jadi_tanggungjawab_pemerintah_dan semua_lapisan_masyarakat.html pada 8 $\overline{\text { Februari }} 2016$.

2 Dinas Kesehatan RI. 2013. Survei Kesehatan Rumah Tangga 2013. Jakarta.

3 Stanhope, M; Lancaster, J, 2012. Community Health Nursing. Process and Practice for Promoting Health. Mosby Year Book, St. Louis-Toronto.

4 Green, L.W; Kreuter, M.W. 2000. Health Promotion Planning: En Educational and Environmental Approach, MountainLondon: Mayfield Publishing Company.

5 Atkinson, S; Monica El Haj. 1997. Domain Analysis for Qualitative Public Health Data. Oxford University Press.

6 Badan Pusat Statistik, 2001, Statistical Year Book of Indonesia.

7 Goverment in South of Australia. 2010. Guide for Maternal and Neonatal Services.

8 Hasan Sadikin Hospital. 2002. Medical Record, Bandung, West Java. Unpublished.

9 Hasan Sadikin Hospital. Nursing Care Standard. Direktorat Medik dan Keperawatan.

10 Local Goverment System Indonesia. 2010. Indonesia Country Report.

11 Maternity Staffing Levels (Midwifery \& Nursing Staff)

12 Ministry of Health and Population. 1997. Cost Analysis and Efficiency of Health Care. Data for Decision-making, Harvard School of Public Health, University of California, Berkeley, School of Public Health

13 Untoro, R., Sri Hermiyanti, Chazali Husni 
Situmorang., Abas Basuni. 2009. Healthy Next Generation: Strengthening Joint Collaboration Between Health and Social Welfare. Indonesia Country Report. 8-11 September 2009 Tokyo, Japan The 6th ASEAN \& Japan High Level Officials on Caring Societies.

14 WHO. 2008. Indonesia Mortality Country Fact Sheet.

15 WHO, 2009. Global standards for the initial education of professional nurses and midwives, Geneva.

16 WHO.2010. Nursing Midwefery Strategies
Direction 2011-2015, Geneva Switchzerland 17 The Future of Nursing: Leading Change, Advancing Health http://www.nap.edu/ catalog/12956.html

18 ICN. 2006. The Global nursing shortage: Priority areas for intervention: Geneva, Switzerland.

19 ICN. 2008. An aging nursing workforce http:// www.icn.ch/matters ageing Workforce.htm (accessed January 15, 2009).

20 ICN. 2009a. The role and identity of the regulator: An international comparative study: Geneva, Switzerland: Author. 